\title{
A marine Turbellaria Planocera crosslandi (Laidlow, 1903) at Fayed-Great Bitter lake- Suez Canal, Egypt
}

\author{
Samir Beltagi \\ Department of biological and geological sciences
}

\begin{abstract}
This research work has its taxonomical and zoogeographical importance and had taken into consideration the detailed description of the male and female genital systems of the Turbellaria Planocera crosslandi from Fayed-Great Bitter lake- Suez Canal, Egypt. New scientific findings were added, regarding the different types of chitinous spines to the internal epithelium regarding the cirrus of the male copulatory organ. Moreover, a detailed description of the Nervous system had been done, also the sense organs.
\end{abstract}

Key words: Red sea turbellarians- marine ecology - Suez Canal.

\section{INTRODUCTION}

As very little scientific work had been done in the field of Marine turbellaria especially in the Red sea, it was really encouraging to undergo taxonomical and zoogeograpgical research work upon collected turbellarians from the shallow water in the region of the western side of the Great Bitter lake at the Suez Canal.

It is quite obvious that few scientists in this field concerning Polyclad turbellarians had offered their work especially in the different parts of the Red sea, for eg., Cestoplana polypore a Polyclad collected from Kosseir also Stylochus reticulata. Ehrenberg ${ }^{(1)}$ in 1831, had discovered Stylochus suesensis from Tor and Port Suez. Leuchart 1828, collected limbata from Tor. Leptoplana nadiae was collected from Ghardaqa. Palombi ${ }^{(2)}$ in 1928 discovered Craspedomata sp. From gulf Suez. In addition to that, other work had been done on Acoelan Turbellarians in the Red Sea by Antonius ${ }^{(\mathbf{3})}$; Beltagi $^{(\mathbf{( 4 )}}$; Beltagi \& Khafaji, ${ }^{(\mathbf{5})}$.

\section{MATERIALS AND METHODS}

It is worth mentioning that this species is collected in May 2017 at a depth of $20 \mathrm{~cm}$ from the water surface at the western part of Fayed (Fig. 1).

The collection comprises 15 specimens, some of which are large and fully mature, while others are small and present different stages of sexual maturity.

The animal is successfully fixed by sudden killing, using hot sublimate Bouins solution without previous narcotistion. After 48 hours fixation in Bouins solution, the animal is washed completely in $70 \%$ ethyl alcohol, which is considered its preservative. Borax carmine, as well as Delafields hematoxylin are used in staining whole mount preparation.

In this work, reconstructions of this species were done from serial transverse, longitudinal and median sagittal sections of the thickness $8-10 \mathrm{~mm}$, using rotary microtome.

Characlteristic Features: (Figs. 1, 2, 3,4)

The animal is oval in shape and dorso-ventrally flattened. Its anterior tip is rounded with a blunt posterior end. It has a length which varies between $2-3 \mathrm{~cm}$, and a maximum breadth of 1 to $2 \mathrm{~cm}$, especially at the middle part of the body. The animal has a dirty white coloration. Symbiotic algae are totally missing. There is a pair of short conical nuchal tentacles, (nt) which are situated dorsally nearly at the end of the first sixth of the body. Each non-retractile nuchal tentacle has a length of about $3 \mathrm{~mm}$ and a basal rounded part of 1-2 $\mathrm{mm}$. 


\section{Samir Beltagi}

\section{Internal anatomy:}

I- Digestive system:(Figs. 1, 2,3)

The mouth aperture (Figs. 1, 2,10) is situated mid-ventrally, nearly in the center of the body. It is circular and is provided with radial and circular muscle fibres from the ventral subepithelial musculature. It leads to the pharyngeal cavity. The pharynx is of the ruffled type (Figs. 1,2) and hangs down from the dorsal wall of the pharyngeal cavity as a much frilled or ruffled circular, whose attachment is also sinuous and whose folds are accompanied by corresponding pouches of the pharyngeal cavity (Figs. 3, 4).

The intestine (Figs. 1, 2 ) consists of the central intestine, a median tube that lies above the ruffled type of pharynx (Plicatus) and gives numerous branches (its number is seven on each side) oriented the periphery. The intestinal caeca (Figs. 1,2) are numerous and are nonanastomosing. The intestinal epithelium consists of tall columnar epithelial cells.

\section{Structure of the body wall:}

The animal is clothed in a completely ciliated cellular epidermis which is formed of one layer of narrowed basally columnar epithelial cells. The epidermal layer is generally separated from the underlying mesenchyme by a definite basement membrane. Rhabdite gland cells and mucus gland cells are existing.

The sub-epidermal musculature forms a stratum just beneath the basement membrane. It is more powerfully developed ventrally than dorsally and often thins towards the margin and anteriorly.

The ventral sub-epidermal musculature consists of six layers:

a) Outer circular muscle layer.

b) Inner longitudinal muscle layer.

The parenchymatous musculature consists of dorso-ventral, transverse and longitudinal muscle fibres. The dorso-ventral muscle fibres are the best developed, and there are strong longitudinal muscle bundles in the ventral msenchyme.

\section{Nervous system:}

It is formed of an internal bilateral central brain mass (Figs. 1, 2) It is enclosed in a capsule. A fine sub-epidermal nerve net is generally found in the animal and among most of the polyclads.

It is formed of a centralized brainmass, located at the first antesiord air the part of the body at the side of the body.

The brain mass is formed a ganglionic masses each of which give to six mewecords as follows:

1- The anterior nerve cord. (fig. 10, anc)

2- The antero lateral nerve cord. (fig. anlc)

3- The ventral medio nerve cord. (fig. vnc)

4- The dorso-medio nerve cord. (fig. adnc)

5- The dorso-latero nerve cord. (fig. alnc)

6- The ventral nervue cord. (fig. vnc)

Each nerve cord gives rise to branches extending until the body margin. These marginal nerve branches subserve in the process of sensory processes.

\section{Sense organs:}

1- Nuchal tentacles

They are consided to be chema and tango receptors and of the inners type.

2- Eyes are absent at the peripheral part of the body. 


\section{A marine Turbellaria Planocera crosslandi (Laidlow, 1903) at Fayed-Great Bitter lake- Suez Canal, Egypt}

3- Dermal eyes are distributed randomly.

4- Cerebral eyes are present.

5- Tentacular eyes are present.

Arrangement of the Eyes : (Figs. 1, 2, 3, 4)

As a matter of fact, the arrangement of the ocelli and their sizes and their location are considered to be an important systematic characteristics of great value.

1- Marginal Eyes:

These are totally missing.

2- Tentacular Eyes: (Fig. 1, 2, 3 )

They are coarse black ocelli and clustered at the base of each tentacle, the number of which varies from 48 to 52 .

3- Cerebral Eyes: (Fig. 2, 2, 4)

These are a group of black ocelli clustered in a large number in the region of the brain mass. They are divided into 2 very closely situated groups (Fig. 1, 2, 4). Each ocellus is oval in shape. Their number varies from 120 to 125 on each side.

4- Frontal Eyes:

These are absent.

5- Few sub-epithelial eyes are randomly distributed along the whole length of the body.

\section{The Reproductive system:}

Male genital system: (Figs. 1, 2, 5, 6, 7)

The testes (Fig. 2, 6-t) lie chiefly in the ventral part of the body and are embedded in the parenchymatous tissue. A pair of seminal canals (Fig. 2-sc) proceed forward from the hindbody to the level of the prostate vesicle (Fig. 1, 2, 5, 6-sv) as in the case of Planocera profunda ${ }^{(6)}$, and here turn mediad to join into a single duct in the median level, which extends into an oval seminal vesicle (Fig. 1, 2, 5, 6) which is strongly muscularised. Issuing from the postero-dorsal aspect of the seminal vesicle, a narrow tubular ejaculatory duct (Figs. 5, 6) extends posteriorly and ventrally in relation to the spherical prostate vesicle, where it unites with its short duct. It extends spirally and in a twisted way inside the muscular cirrus (Figs. 1, $2,5,6,7)$. The cirrus is very spacious and cylindrical extending posteriorly to continue in the antrum musculinum which opens to the exterior by the male genital pore (Figss. 1, 2, 3). The internal epithelium of the cirrus cavity is beset with minute chitinous spines which is differentiated into two types:

a) The dorsal surface of the internal cavity of the cirrus is covered by chitinous spines of a triforked inner endings.

b) Monaxon and needle-like chitinous spines are existing upon the inner latero-ventral epithelial layer of the cirrus. Moreover, the posterior region of the cirrus cavity bears three large triangular hook-like chitinous structures (Figs. 1, 2, 6, 7) similar to that Planocera crosslandi ${ }^{(7)}$.

\section{Female Genital system:}

The ovaries (Figs. 1, 2, 5) are distributed in the dorsal parenchymatous tissue. The female genital pore (Fig. 1, 2-fgp) opens directly into a Bursa copulatrix (Figs. 1, 2, 5) which is large and oval surrounded by a thick muscular coat of circular, longitudinal and radial muscle fibres. The bursa copulatrix is directed anteriorly and leads into a wide vagina media (Figs. 2, 5) which functions mostly as a shell chamber (Fig. 2-sgc) being invested with numerous shell gland cells (Fig. 2). It curves posteriorly to receive the common uterine duct 


\section{Samir Beltagi}

(Figs. 2, 5) and then, it extends posteriorly into a narrow rudimentary lang's vesicle (Fig. 2, $5)$.

\section{Diagostic Feature:}

The present animal is greatly similar to the Planocera crosslandi ${ }^{(7)}$

, in most of the essential characters. It is considered to be the first record in the Eulittoral region of the western region of Great Bitter Lake of the at Fayed city of the Suez canal Egypt.

\section{Systematic Position}

Phylum : Platyhelminthes

Class : Turbellaria

Order : Polycladida

Sub order : Acotylea ${ }^{(8)}$

Super family : Craspidommatidea

Family : Planoceridae ${ }^{(8)}$

Genus : Planocera ${ }^{(9)}$

Specas cross landit ${ }^{(7)}$

\section{Acknowledgments}

I would like to thank Prof. Dr.Mohamed Hamed the head of the Biological and Geological Department for his sincere assistance to this research work, and the Assistant lecturer Taha Abd El Shafey and Mr. Magdy Maduen Laboratory specialist.

\section{REFERENCES}

1. Ehrenberg, C.G. (1831). Hemprich et Ehrenberg, Symbolae physicae. Animalia evertebrata exclusis insectis Er. V. G. Ehrenberg; Series prima a tabularum decade prima. Berolini. Fol. Phytozoa Turbellaria Africana et asiatica in phytozoorum tabule IV et V delineate. Foloia a.d.

2. Palombi (1928). Reports on the Turbellaria (Cambridge Exp. Suez Canal 1924). Part 5, Nr. 1.1, Zool. Soc. London 22(1): 579-631.

3. Antonius, A. (1968). Faunisticshe Studien am Roten Meer im winter 1961/62, Teil IV. Neue convolutidae und eine Bearbeitung des verwandtschaftskreises convolute (Turbellaria Acoela). Zool. Syst., 95: 297-394.

4. Beltagi, S. (1983). Anaperus trifurcates nov. sp. (Archoophora: Anaperidae): A new species of Acoelan Turbellaria from the Red Sea. J. Fac. Mar. Sci. Jeddah 3: 49-71.

5. Beltagi, S. and Khafaji, M. (1983). Anaperus trifurcates nov. sp. (Archoophora: Anaperidae). A new species of Acoelan Turbellaria from the Red Sea. Journal of the Faculty of Marine Science, Jeddah, 3: 49-71.

6. Kojiro Kato (1937). Thirteen new polyclads from Miraki, Japanese J. Zool., Vol. VII, No.3.

7. Laidlaw, F.F. (1903). On the Marine Fauna of Zanzibar and British East Africa, from collections made by Cyril crossland in the years 1901 and 1902 Turbellaria Polycladida. Part I. The Acotylea. Proc. Zool. Sco., London, 2: 99-113.

8. Lang, A. (1884). Des Polycladen des golfes von Neapel, 11.

9. Blainville, de, 1826 et 1828. Dictionnaire des sciences naturelles Art. Planarie, 41, 18. 


\section{A marine Turbellaria Planocera crosslandi (Laidlow, 1903) at Fayed-Great Bitter lake- Suez Canal, Egypt}

\section{ABBREVIATIONS}

\begin{tabular}{|l|l|l|l|l|}
\hline adnc & Antero dorsal nerve cord & & mgp & male genital pore \\
\hline aib & anterior & minb & main intestinal branch \\
\hline alnc & Antero laterl nerve cord & mlnc & Mid-lateral nerce cord \\
\hline anc & antero nerve cord & & ms & muscular sheath \\
\hline bc & bursa copulatrix & nc & Nerve commussuse \\
\hline bm & brain mass & nt & nuchal tentacle \\
\hline ce & cerebral eye & oc & Ocellus \\
\hline cec & Ciliated epithelial cell & ph & pharynx \\
\hline cem & Cement second & prd & Prastatic duct \\
\hline cr & cirrus & prv & prostate vesicle \\
\hline crb & cirrus bulb & rod & Common oviduct \\
\hline de & Dermal eye & rov & right ovary \\
\hline dts & Dorsal triforked fibre & rt & right testis \\
\hline ed & ejaculatory duct & sc & seminal canal \\
\hline fgp & female genital pore & sg & seperm \\
\hline in & intestine & intestinal coaecum & sgc & shell gland cell \\
\hline inc & Lateral nerve cord & left ovary & Seminal vesicle \\
\hline lnc & left testis & lang's vesicle & te & tentacular eyes \\
\hline lov & mouth aperture & va & vagina \\
\hline lt & Monaxon chitinous spine & vd & oviduct \\
\hline lv & vm & vagina media \\
\hline ma & vnc & Ventral nerve cord \\
\hline mas & vs & Vesicular semindis \\
\hline
\end{tabular}


Samir Beltagi

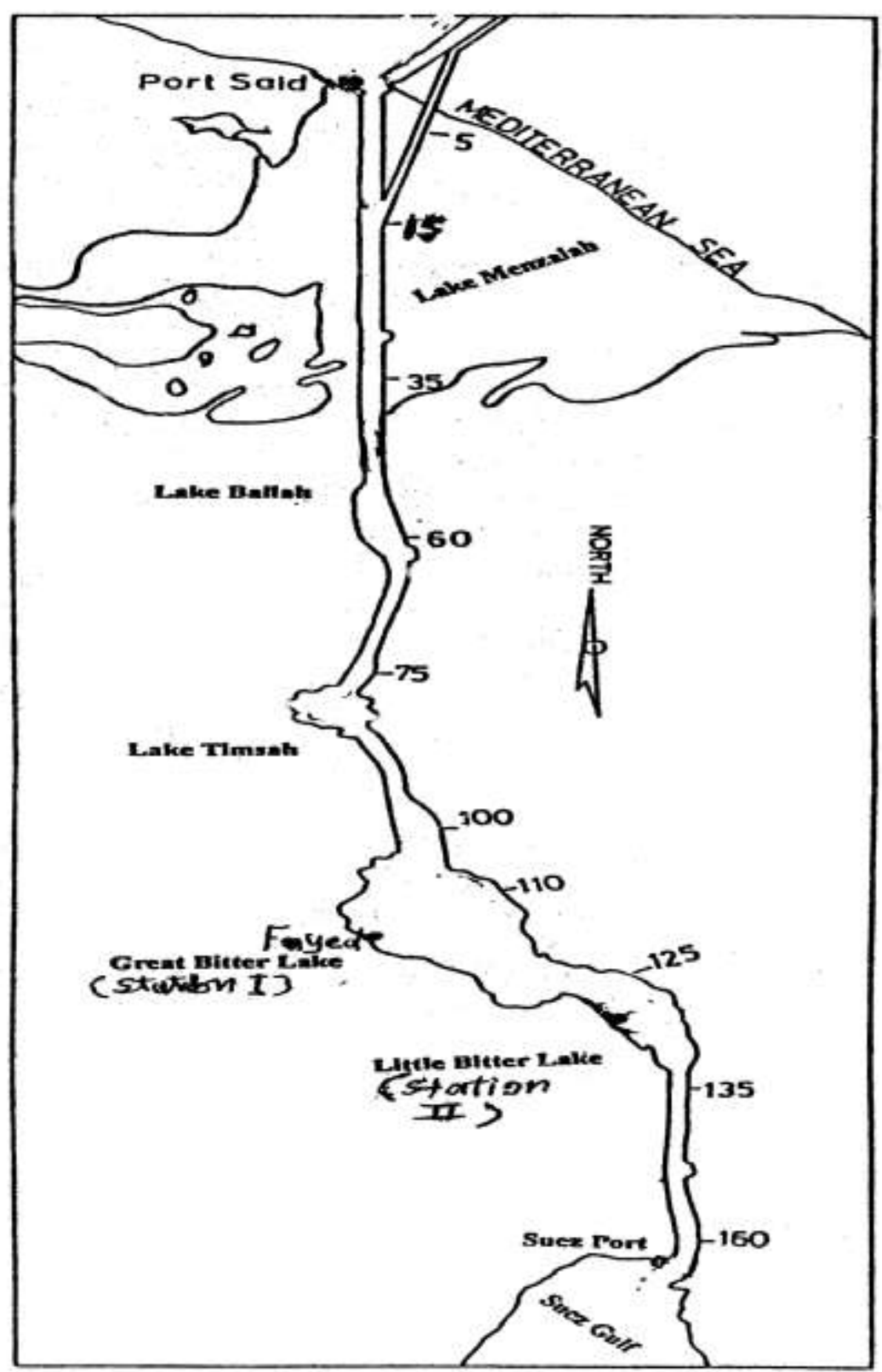

Figure 1: A map of the Suez Canal showing the sampling stations (Fayed) 
A marine Turbellaria Planocera crosslandi (Laidlow, 1903) at Fayed-Great Bitter lake- Suez Canal, Egypt

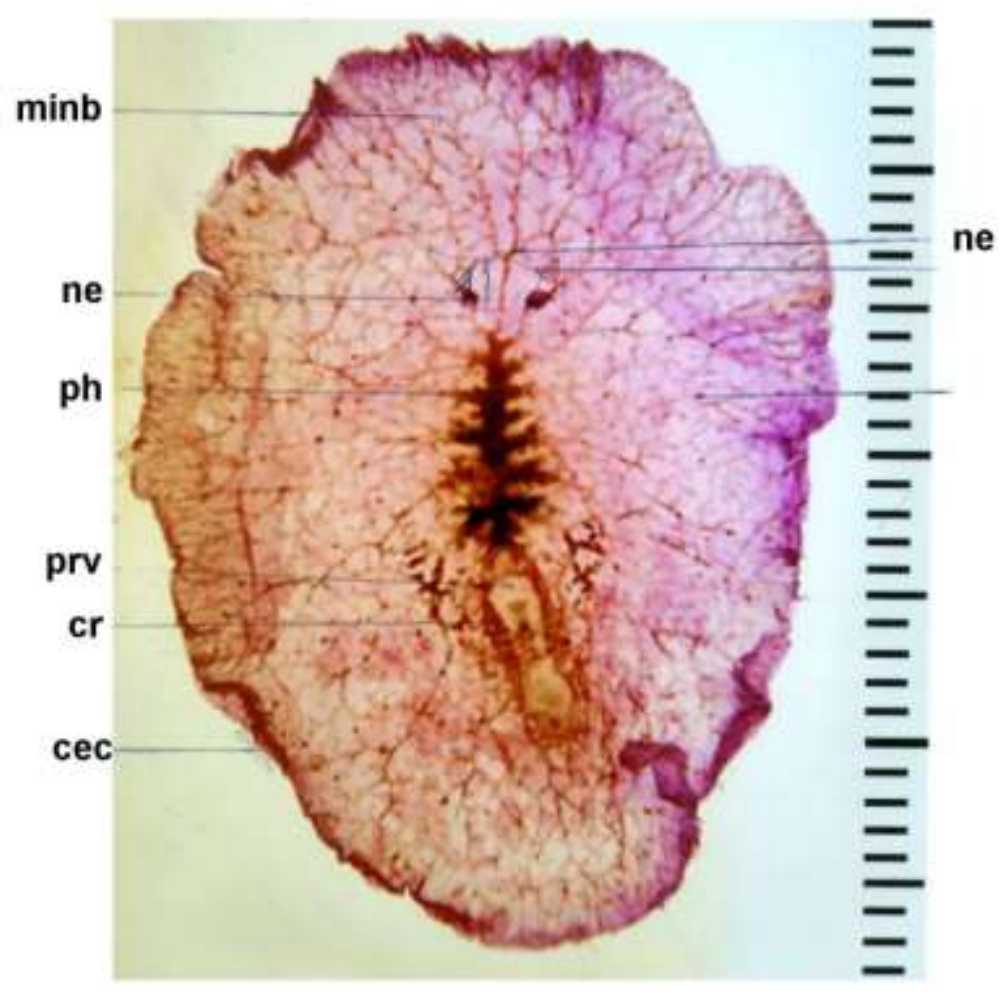

Fig. 2: Showing a assessed animal body

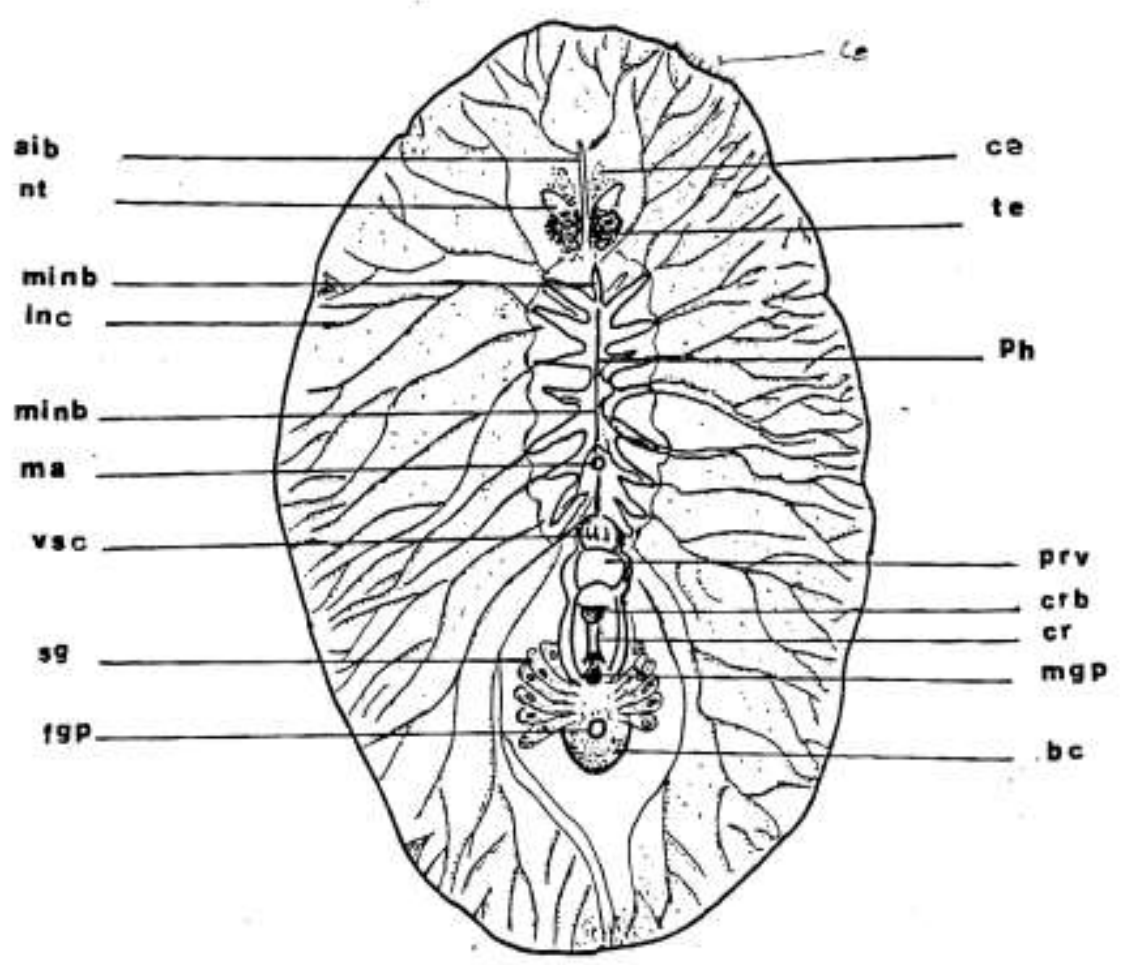

Fig. 3: Planocera crosslandi (Laidlaw)-External features 
Samir Beltagi

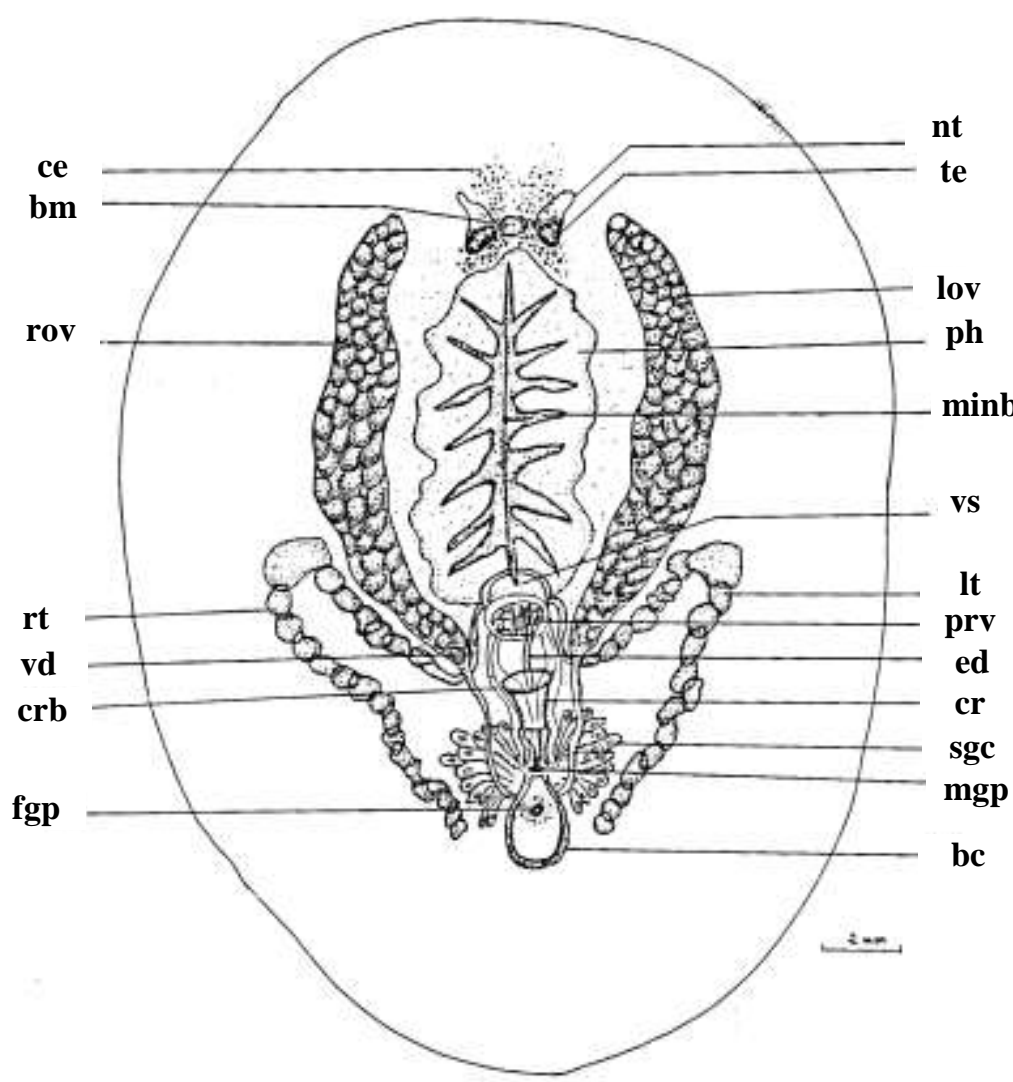

Fig. 4: Planocera crosslandi (Laidlaw, 1903) Enlarged Internal organisation

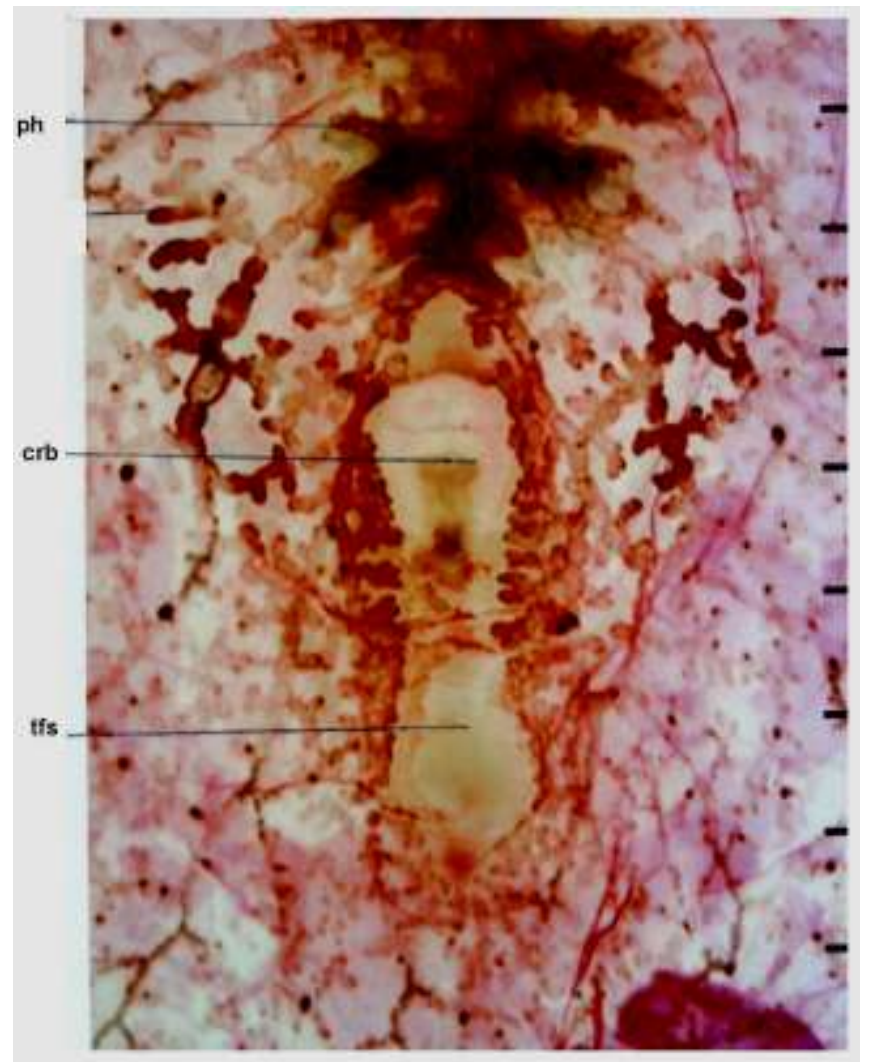

Fig. 5: Micrograph of the Planocera crosslandi (Enlarged) 
A marine Turbellaria Planocera crosslandi (Laidlow, 1903) at Fayed-Great Bitter lake- Suez Canal, Egypt

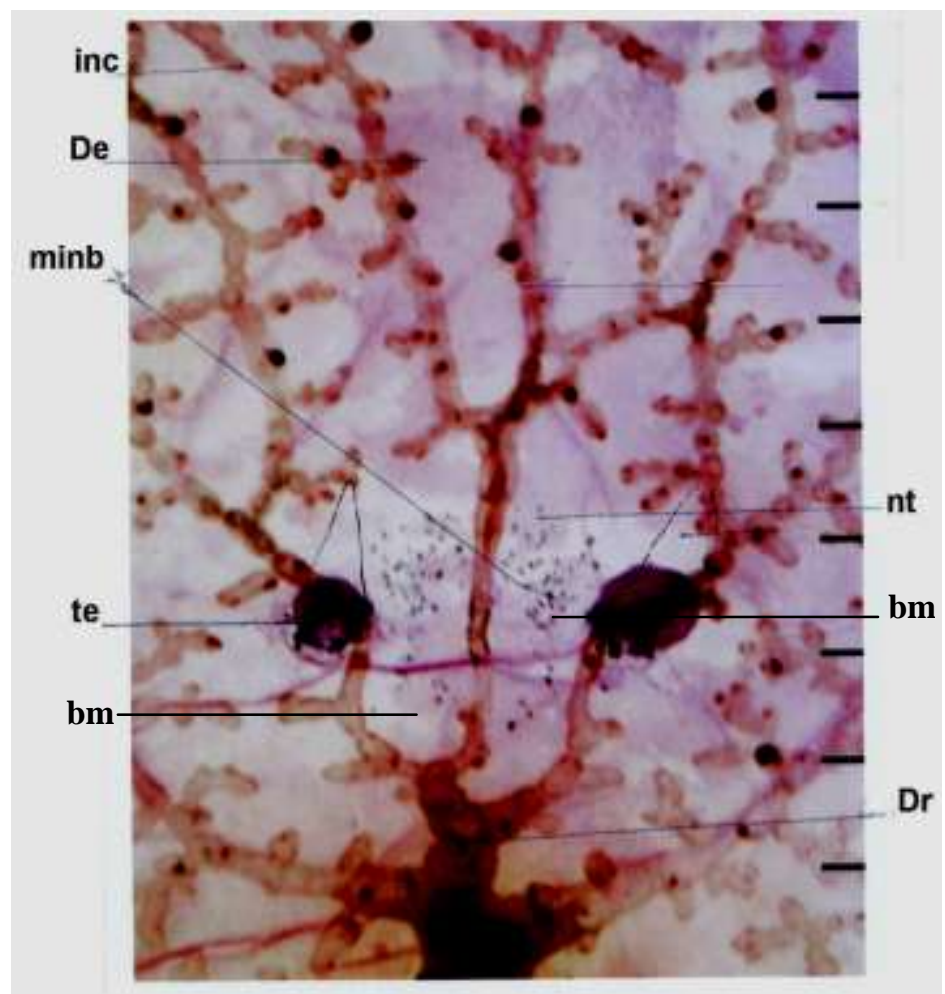

Fig. 6: Photo micrograph of P.crosslandi

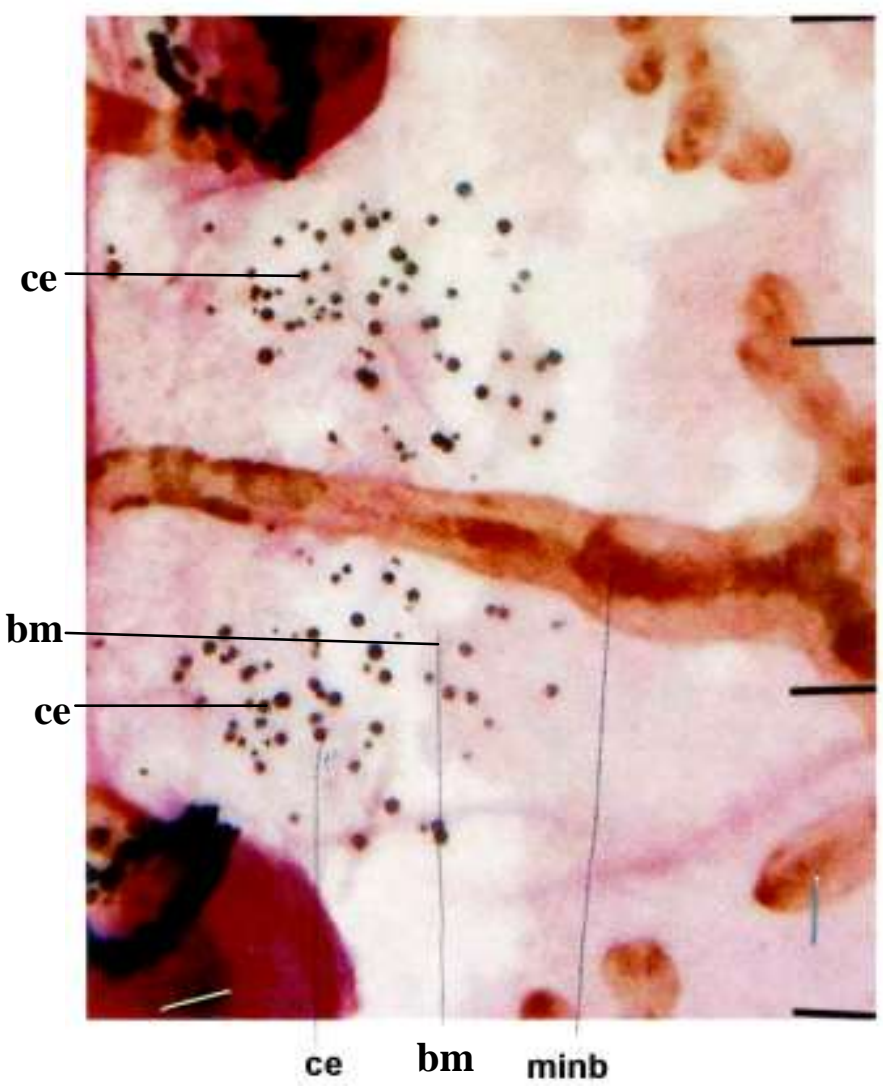

Fig. 7: Brain mass, (enlarged) of P.crosslandi 


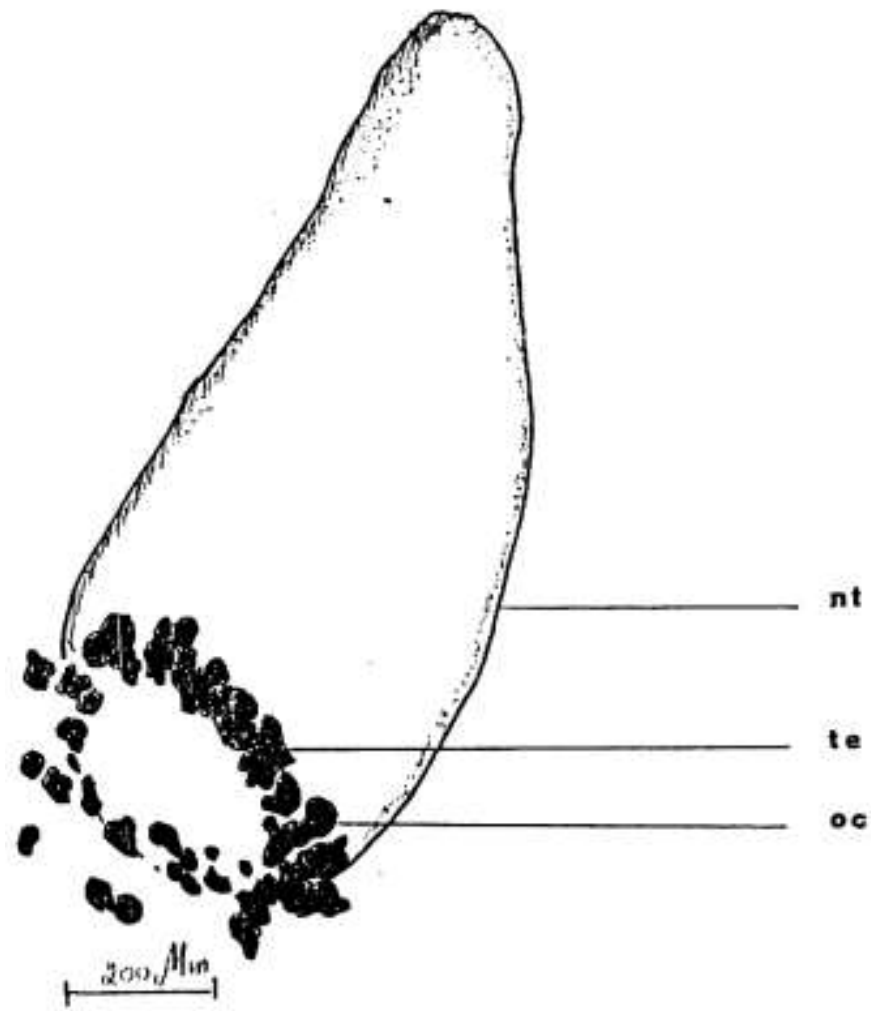

Fig. 8: Planocera crosslandi (Laidlaw, 1903) Enlarged nuchal tentacle and tentacular eyes

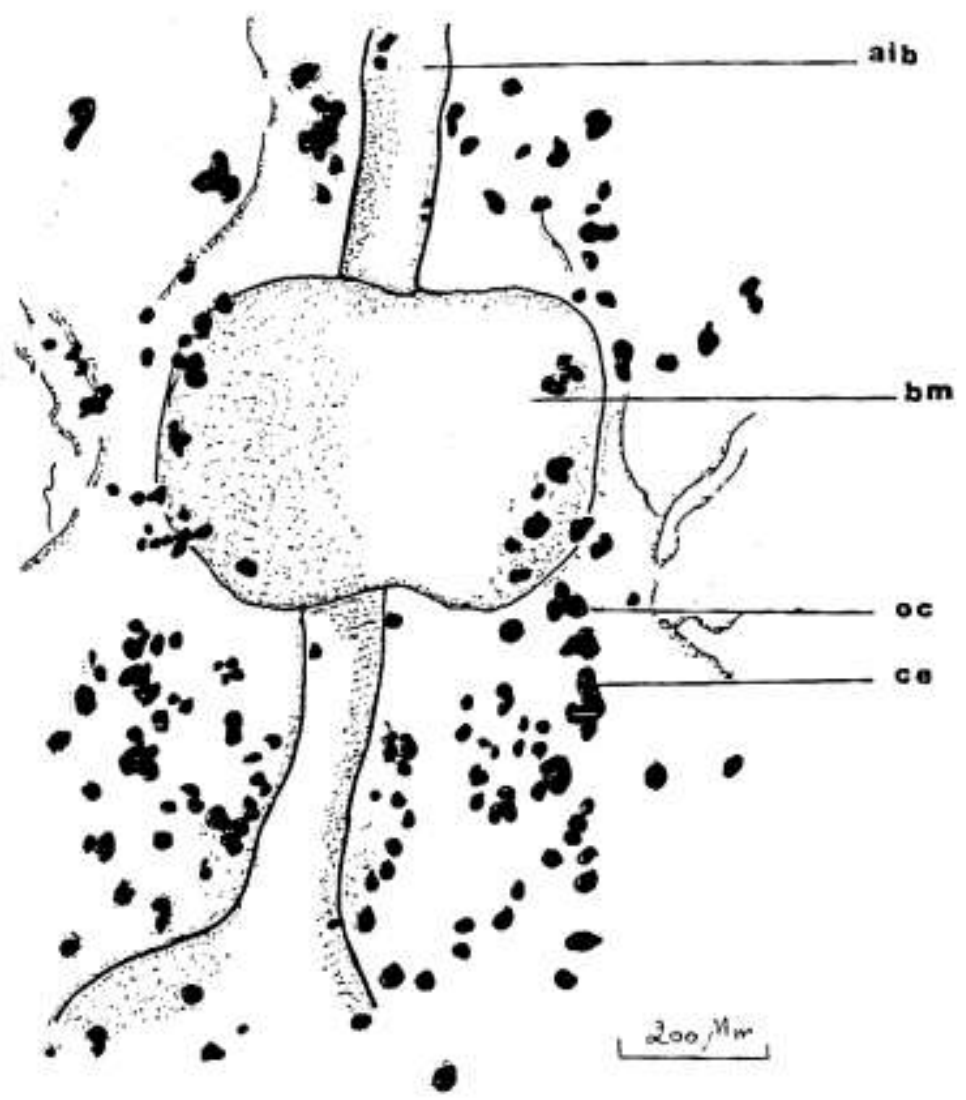

Fig. 9: Planocera crosslandi (Laidlaw, 1903) Enlarged brain mass cerebral eyes 


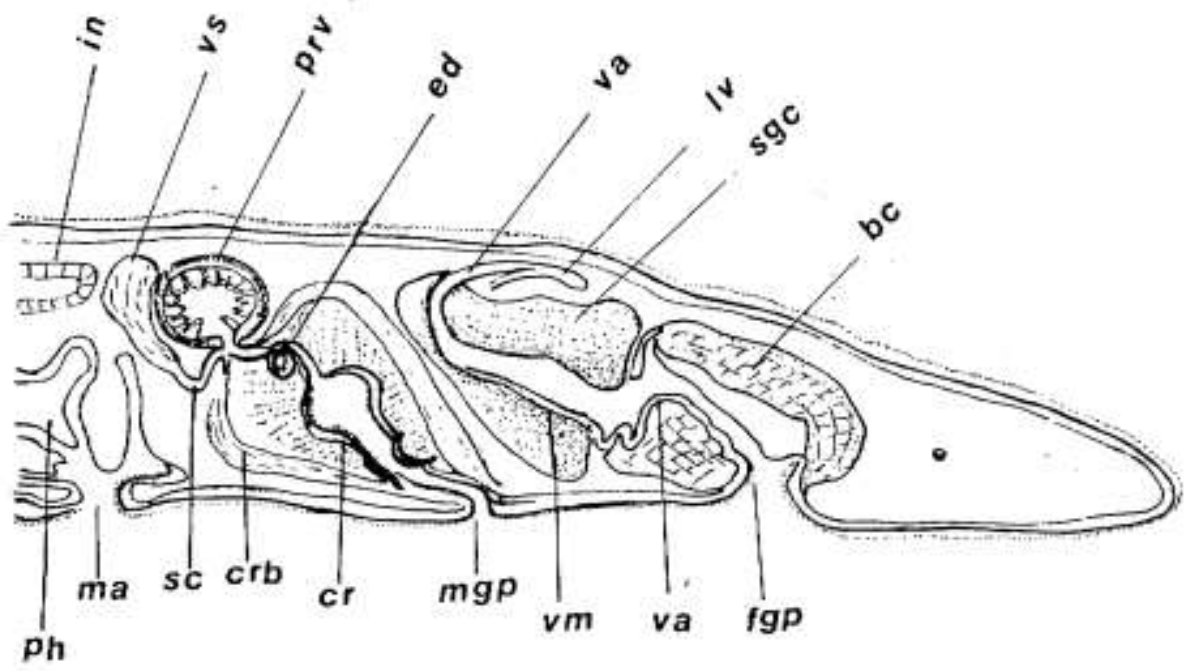

Fig. 10: Planocera crosslandi (Laidlaw) - Reconstruction of the female and male genital systems

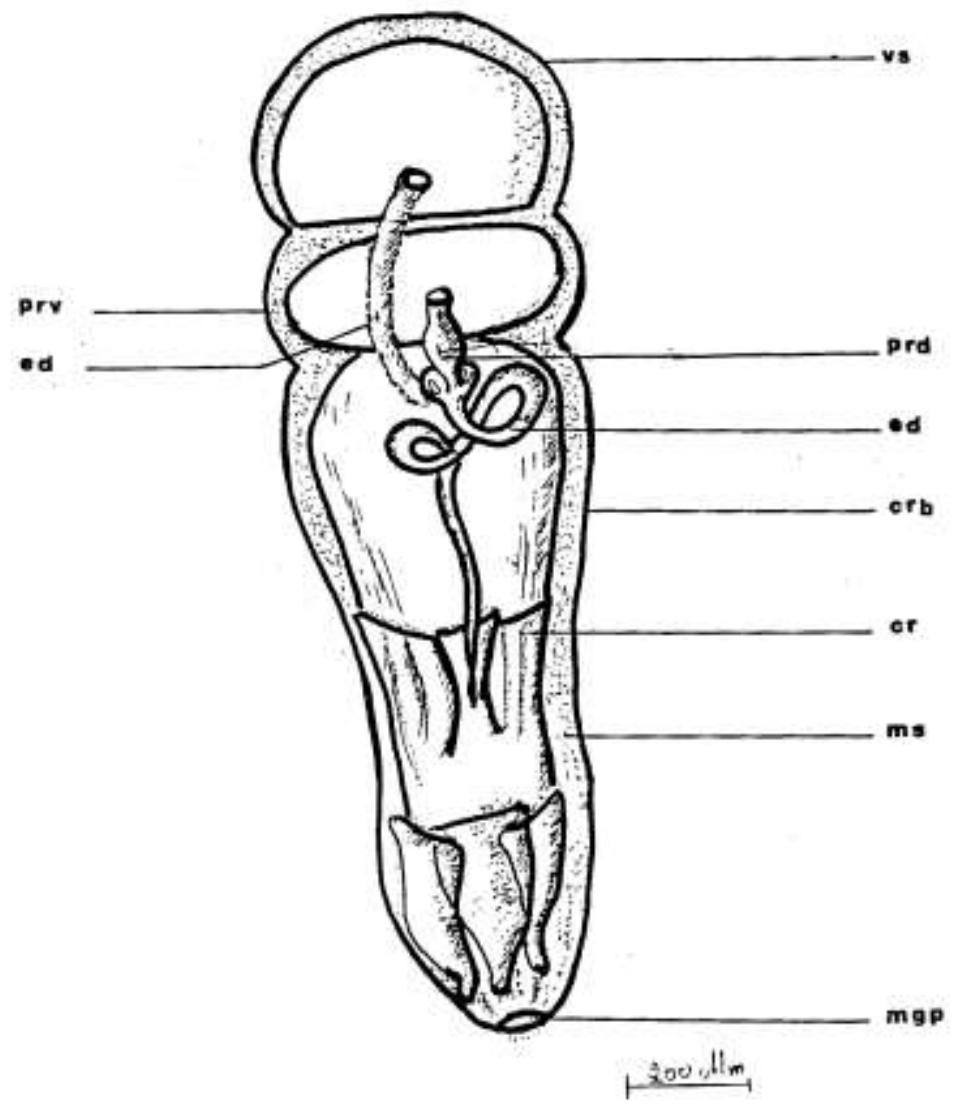

Fig. 11: Planocera crosslandi (Laidlaw, 1903) Enlarged Reconstruction of the male copulatory apparatus 
Samir Beltagi

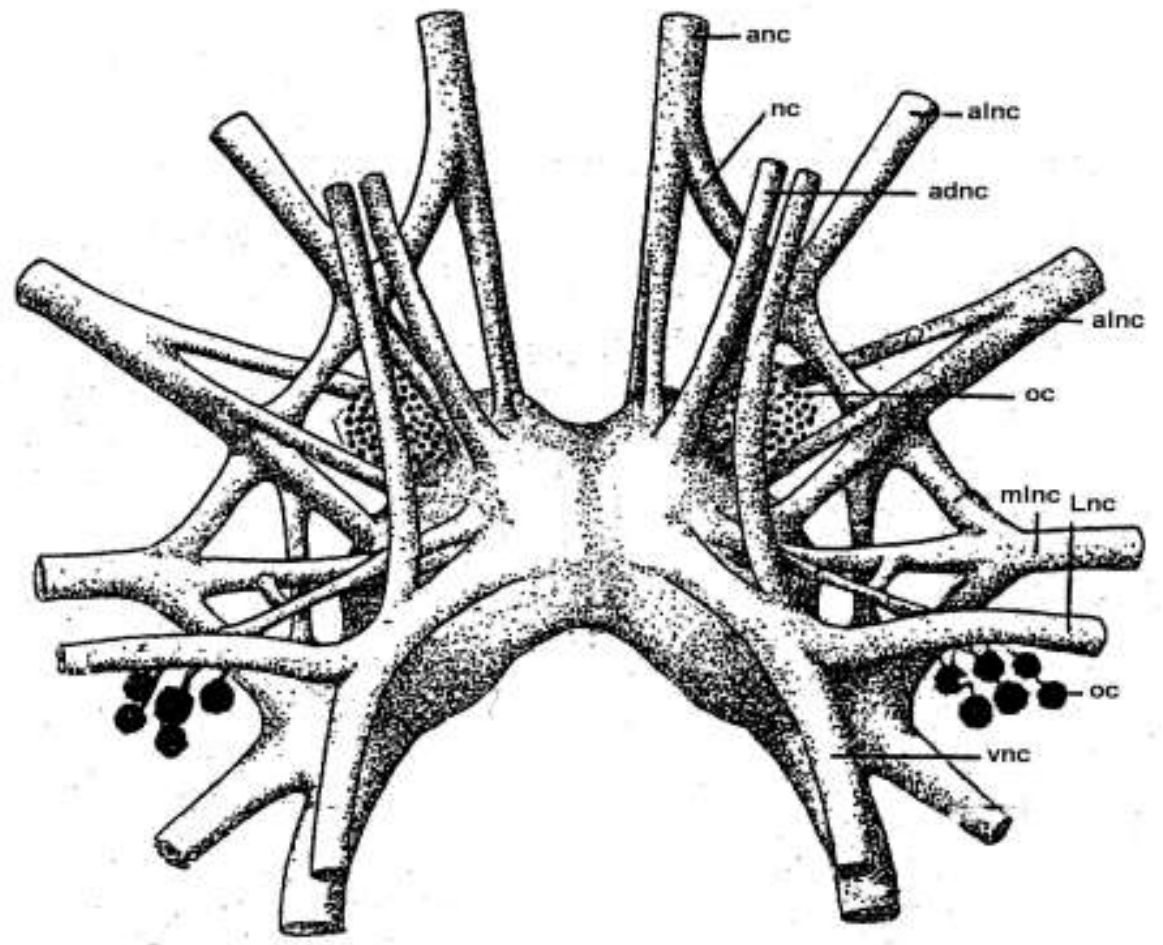

Fig. 12: General view area dorsal surface (enlarged) of P.crosslandi

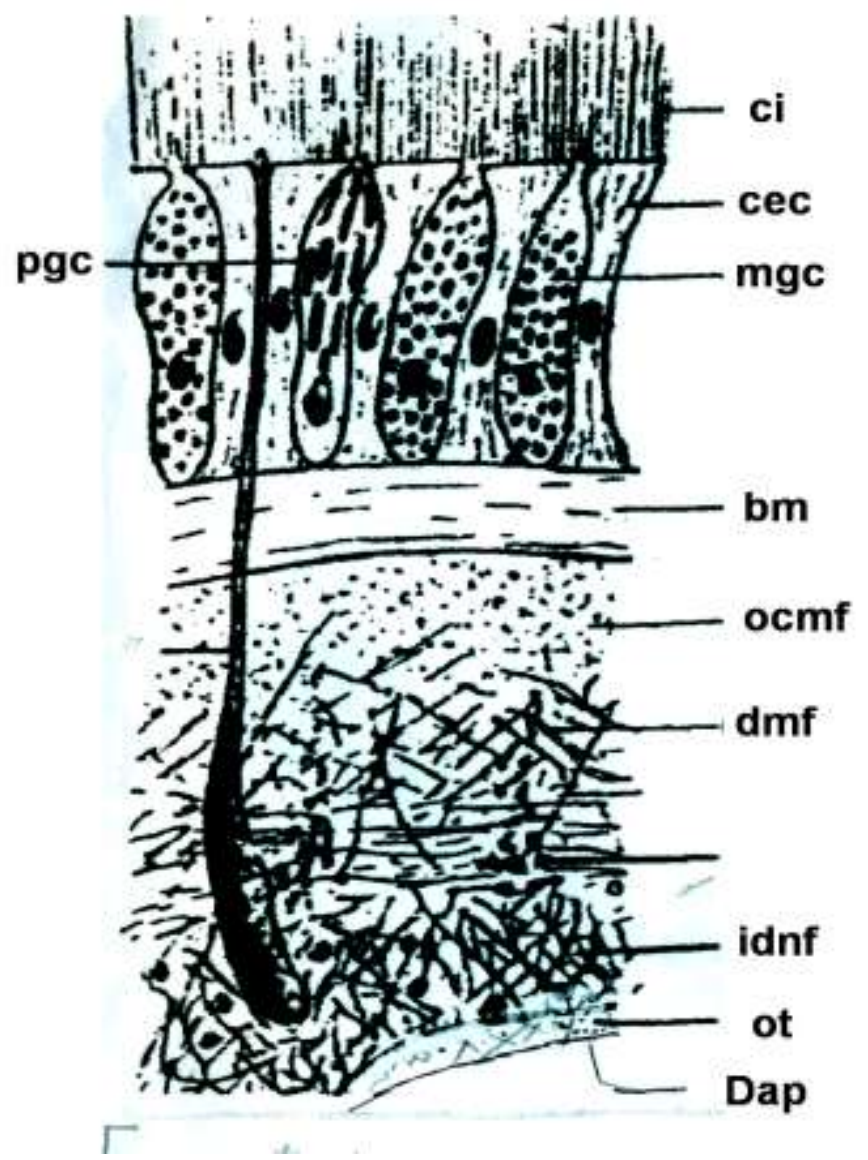

Fig. 13: Body wall the dorsal part (enlarged) of $P$. crosslandi 
A marine Turbellaria Planocera crosslandi (Laidlow, 1903) at Fayed-Great Bitter lake- Suez Canal, Egypt

تربيلاريا بلانوسرا كروسلاندى (ليلولو-1903) فى فايد-البحيرات المرة_قناة السويس-مصر

$$
\text { قسم العلوم البيولوجية وُالجيولوجية }
$$

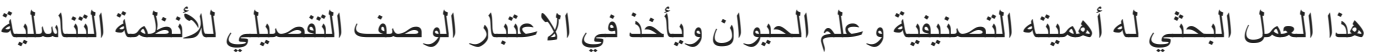

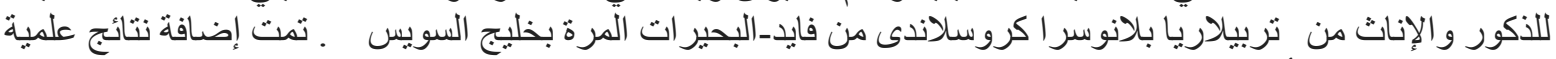

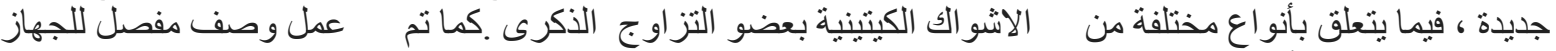
العصبي ، وكذللك الأعضاء الحسية مخئ. 